\title{
High-grading and over-quota discarding in mixed fisheries
}

\author{
J. Batsleer • K. G. Hamon • \\ H. M. J. van Overzee • A. D. Rijnsdorp • \\ J. J. Poos
}

Received: 24 April 2015/Accepted: 16 October 2015/Published online: 27 October 2015

(C) The Author(s) 2015. This article is published with open access at Springerlink.com

\begin{abstract}
High-grading is the decision by fishers to discard fish of low value that allows them to land more valuable fish. A literature review showed high-grading is reported in commercial and non-commercial fisheries around the world, although the number of observations is small. High-grading occurs in fisheries that are restricted to land their total catch due to management, market or physical constraints. Using the mixed flatfish fishery as a model system, a dynamic state variable model simulation showed that high-grading of certain grades occurs throughout the year when their ex-vessel price is low. High-grading increases with the degree of quota restriction, while the level of over-quota discarding is unrelated to the quota level. The size composition of the high-graded catch differs from the landed catch. Due to the differences in the seasonal variation in size specific ex-vessel price, the effect of quota restrictions
\end{abstract}

J. Batsleer $(\bowtie) \cdot$ H. M. J. van Overzee ·

A. D. Rijnsdorp · J. J. Poos

IMARES, Institute for Marine Resources and Ecosystem

Studies, P.O. Box 68, 1970 AB IJmuiden,

The Netherlands

e-mail: jbatsleer@visned.nl

J. Batsleer · A. D. Rijnsdorp

Aquaculture and Fisheries Group, Wageningen University, P.O. Box 338, 6700 AH Wageningen,

The Netherlands

K. G. Hamon

Agricultural Economics Research Institute (LEI), P.O. Box 29703, 2502 LS Den Haag, The Netherlands on the size composition of the discarded catch is nonlinear. High-grading is difficult to detect for the fishery inspection as it occurs on-board during the short period when the catch is processed. We conclude that highgrading is under-reported in fish stocks managed by restrictive quota, undermining the quality of stock assessments and sustainable management of exploited fish stocks.

Keywords By-catch · Discards · Common fisheries policy $\cdot$ Fisheries management $\cdot$ Flatfish

\section{Introduction}

Many fisheries around the world capture fish that are subsequently discarded back into the sea (Kelleher 2005). Discarding is mainly policy or market driven. Policy measures such as legal landings sizes or catch quota may forbid selling small fish (Harley et al. 2000; Rochet and Trenkel 2005; Depestele et al. 2011; Feekings et al. 2012) or over-quota catches (Copes 1986; Branch 2009; Poos et al. 2010), while market incentives prevent the sale of certain (by-catch) species or size classes (Gray and Kennelly 2003; Hara 2013; Eliasen et al. 2014).

Discarding of marketable fish in fisheries that are under catch quota management are of particular interest. Catch quotas or "Total Allowable Catches" (TAC) are used worldwide to regulate fisheries. The 
intention of catch quotas is to control fishing mortality of a given stock to a specified level (e.g. to prevent overfishing). The use of such quotas relies on the premise that fishers adjust their fishing behaviour according to imposed catch limitations (Holden 1994; Daan 1997; Punt et al. 2006; Branch and Hilborn 2008). However, in reality TACs may control landings of fish but not the catch, because fishers may continue to fish and discard marketable fish exceeding the quota, as is likely in mixed fisheries (Pascoe 1997; Poos et al. 2010). As a result, the effectiveness of TAC management of mixed fisheries is questionable (Daan 1997).

As a refinement of the TAC system, individual transferable quotas (ITQs; Christy 1973) have been introduced world-wide to stop the "race for fish" (Copes 1986; Arnason 1993; Squires et al. 1998). ITQs provide a share of the TAC to participants in a fishery who are allowed to sell and lease their share of the quota (Davies 1992). Having rights to predetermined shares of the resource output, fishers can plan their fishing effort to secure their share of the catch, without having to account for the catches of other fishers. Although the ITQs have generally been considered successful (Branch 2009; Hamon et al. 2009; Hannesson 2013; Soliman 2014), they have not completely taken away the incentive for discarding parts of the marketable catch. Given that the quota is a predetermined share, fishers can optimize the economic return by "high-grading" their catch: that is to say, discarding those parts of the marketable catch that have the lowest value while quota is still available. Also in mixed fisheries, fishers can discard marketable fish once their quotas have been reached, termed "overquota discarding". The survival of the discarded fish can be low (Van Beek et al. 1990; Yergey et al. 2012), depending on the type of fishery (Van Beek et al. 1990; Campbell et al. 2014), depth of catch (Sauls 2014), and other factors (Smith and Scharf 2011; Marçalo et al. 2013). Because the survival of the discarded fish can be low, high-grading is considered to be a waste of resources. In response, in 2009 the EU declared highgrading an illegal practice (Regulation (EU) 43/2009).

Theoretical studies suggest over-quota discarding and high-grading occur under specific conditions (Anderson 1994; Turner 1997; Parslow 2010; van Putten et al. 2012). However, empirical evidence for high-grading is scarce, although there is anecdotal information from the fishing industry. High-grading is not only an unknown contribution to the waste of food resources, it may also reduce the accuracy of stock assessments that underpin the management of many fish stocks. Such stock assessments often rely on the age or length structure of the catches to estimate mortality in fish stocks. In the absence of observations of catches, landings are sometimes used as a proxy for catches. Since high-grading affects the age and length structure of the landed fish, the resulting stock assessment may lose accuracy in estimating the mortality and stock size, undermining the credibility of fisheries management (McCay 1995; Daan 1997; Rijnsdorp et al. 2007). Several studies have highlighted the importance of incorporating discards in stock assessments and propose methodologies for their inclusion (Punt et al. 2006; Aarts and Poos 2009).

This paper reviews literature on high-grading and over-quota discarding observations from different fisheries around the world, collating empirical evidence from a wide range of fisheries to study the conditions under which this may occur. In addition, we present a case study that applies a behavioural model to study high-grading decisions of fishers in a Dutch beam trawl mixed fishery under individual quota management (Gillis et al. 2008). This fishery is known for discarding marketable fish (Quirijns et al. 2008; Poos et al. 2010). The model assumes that a fisher chooses a strategy that maximizes annual net revenue. Size structured catches allow exploring the consequences of quota management on discarding of less valuable market size classes in time. The results allow us to forecast over-quota discarding and high-grading and explore the effect on age composition and the implications for stock assessment.

\section{Literature review}

A list of original publications on observations of highgrading and over-quota discarding was derived from literature searches. First a search in Scopus on highgrading was done using the query 'TITLE-ABS-KEY ((("high-grading" OR "highgrading") OR “individual quotas" OR ("individual" AND "quotas" AND "strategy") OR (discard* AND ("minimum landings size" OR "minimum legal length" OR "commercial species" OR “legislation”))) AND (fish*))'. This query thus included search terms for high-grading, and for terms that were expected to be linked to high- 
grading observations. Papers that contained observations on high-grading, such as on-board observations, interviews, or skipper logbooks were included in the review. Papers hypothesizing high-grading based on conceptual models were not considered. Review papers were not included, but the original references were evaluated. In total, 336 papers were screened from which 44 contained observations on high-grading. For each of these 44 papers, the gear type, main species, geographical area, management system, type of observation, and a short description of the observation were recorded. Table 1 summarises the papers that report empirical observations of high-grading. Thirty of these reported observations were made by on-board observers. The fourteen other observations were mostly obtained by interviews, or self-sampling. In most cases where on-board observers were present, high-grading was inferred by generating sigmoid curves describing the length-based retention of individuals, and comparing these to minimum landing size (MLS) regulations. If the length at which $50 \%$ of the individuals was retained was higher than the MLS, this indicates high-grading. In 16 of the papers, the authors mentioned the existence of high-grading in the title or abstract of paper. For the remaining 28 papers, the existence of high-grading was mentioned in the text of 17 papers, or inferred by us in the other 11 . In general we inferred the existence of high-grading when (1) length-structured discards observations showed that fish larger than the MLS was discarded, or (2) there was a clear size difference between landings and discards in the absence of an MLS.

High-grading is reported from a wide range of areas and jurisdictions. In Europe, high-grading is observed in fisheries ranging from the Mediterranean Sea to the North-east Atlantic. In North-America, high-grading is reported in the Gulf of Mexico and the East coast. Additional observations are from Turkey, Greenland, New Zealand, Australia, and South Africa. The existence of some form of individual quotas in the fishery was mentioned in 18 papers. Other fisheries where individual vessels were able to plan the use of quota, such as trip limits and bag limits, also reported high-grading. The relatively large number of papers that are associated with ITQs may in part result from our query. Also, the concerns about high-grading in ITQ fisheries may have spurred empirical research into high-grading in those fisheries. Especially in New Zealand, the benefits and costs of adopting ITQs (and associated problems with high-grading) appear to have been well studied. Finally, high-grading was present in at least five fisheries with TAC management. The exact number cannot be inferred from the literature because not all studies exactly specify the management system, while even national annual quota are sometimes subdivided and made available to individual vessels by e.g. producer organisations. Highgrading was not always related to fisheries management, even if extensive management was in place: the literature review resulted in seven papers that explicitly mentioned high-grading because of market condition. Four studies mentioned the constraining hold of the vessel to be a driver for high-grading (Pikitch et al. 1988; Neher 1994; Olbers and Fennessy 2007; Kristofersson and Rickertsen 2009). Lower price categories are high-graded, most often the smaller individuals. However, high-grading of larger individuals is also observed. Most of the observations on high-grading in the literature represent commercial fisheries using a wide range of gears. One paper explicitly studied and mentioned the existence of highgrading in recreational angling.

A second search was done for over-quota discarding, using the query "TITLE-ABS-KEY ((("overquota" OR "overquota") OR "individual quotas" OR ("individual" AND "quotas" AND "strategy") OR (discard* AND ("minimum landings size" OR "minimum legal length" OR "commercial species" OR "legislation”))) AND (fish*))'. The resulting papers were treated similar to the high-grading literature review. However, from the 314 papers resulting from this query, we found only five papers where overquota discarding could be unequivocally inferred. Those papers where wording was sufficiently strong to suggest discarding of marketable fish after quota were exhausted are collated in Table 2. Some of these papers were also included in the high-grading observations. Many papers are not included in Table 2, because the discarding that resulted from constraining quotas can either be high-grading or over-quota discarding (e.g. Richards 1994; Baelde 2001; Brewer 2011; Cullis-Suzuki et al. 2012; Catchpole et al. 2014; Mace et al. 2014).

To summarise, the literature review shows that high-grading is reported from all over the world in a broad range of fisheries, although the number of reports with empirical evidence is small. High-grading occurs in fisheries that are restricted in landing their 


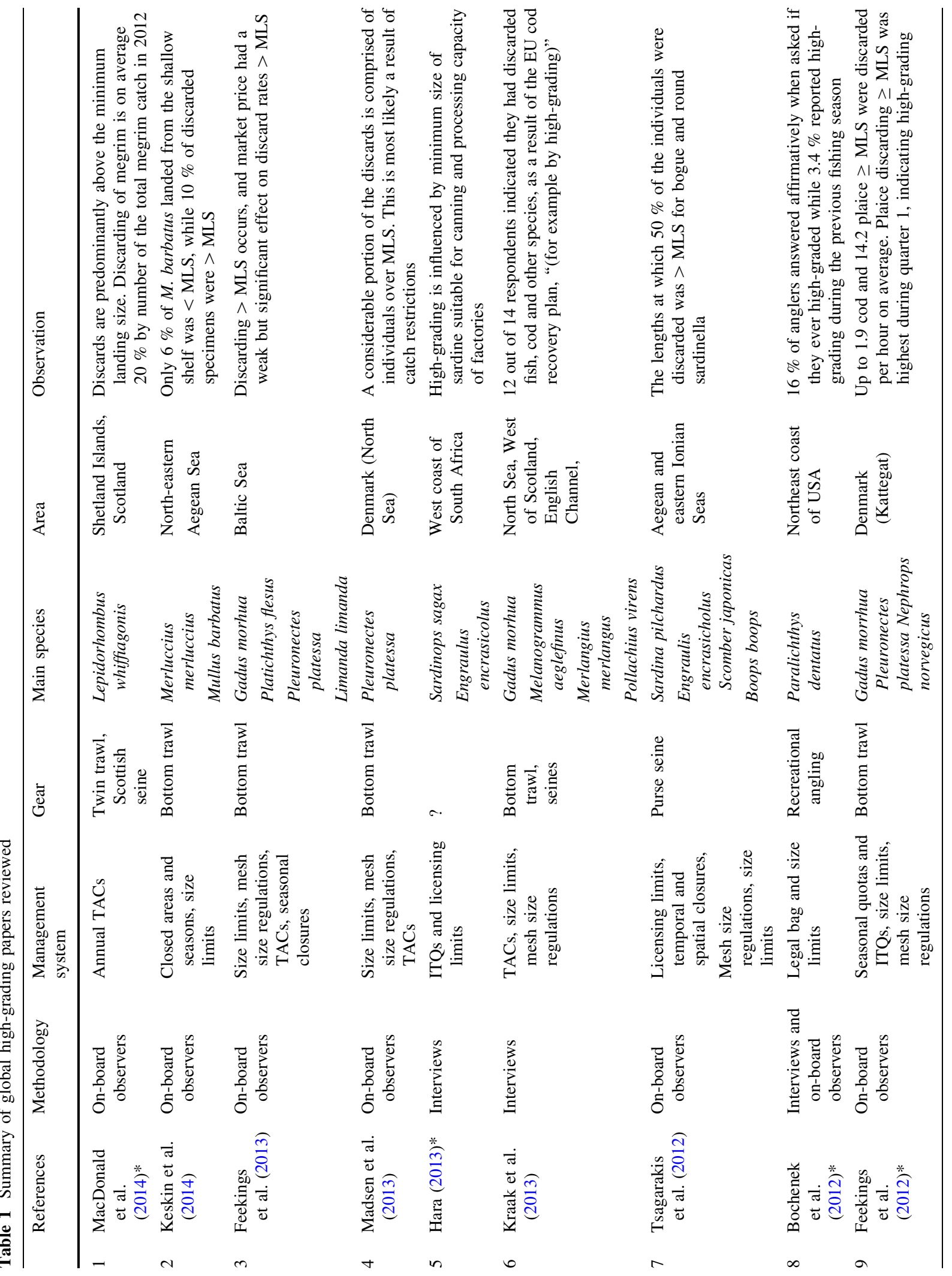




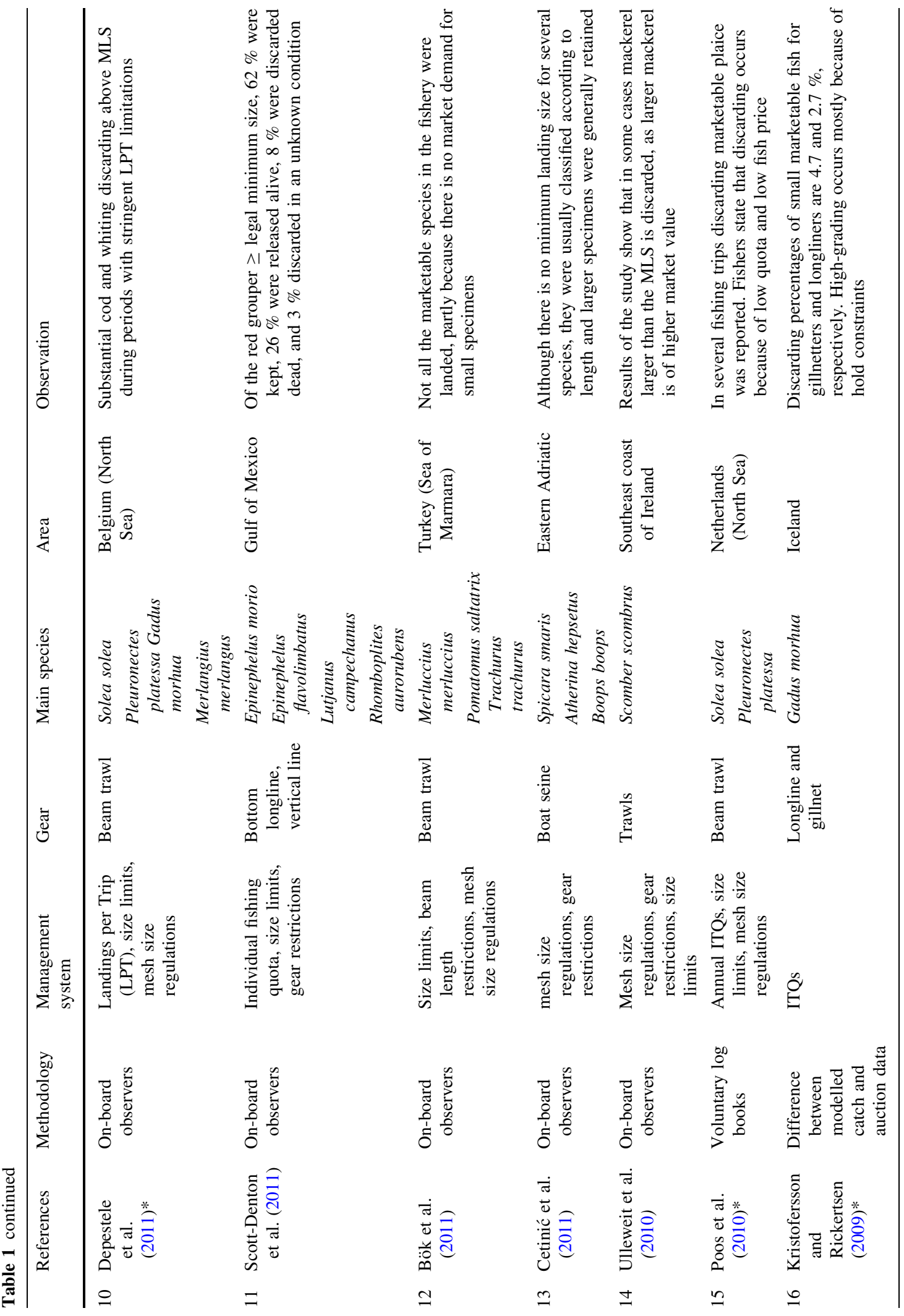




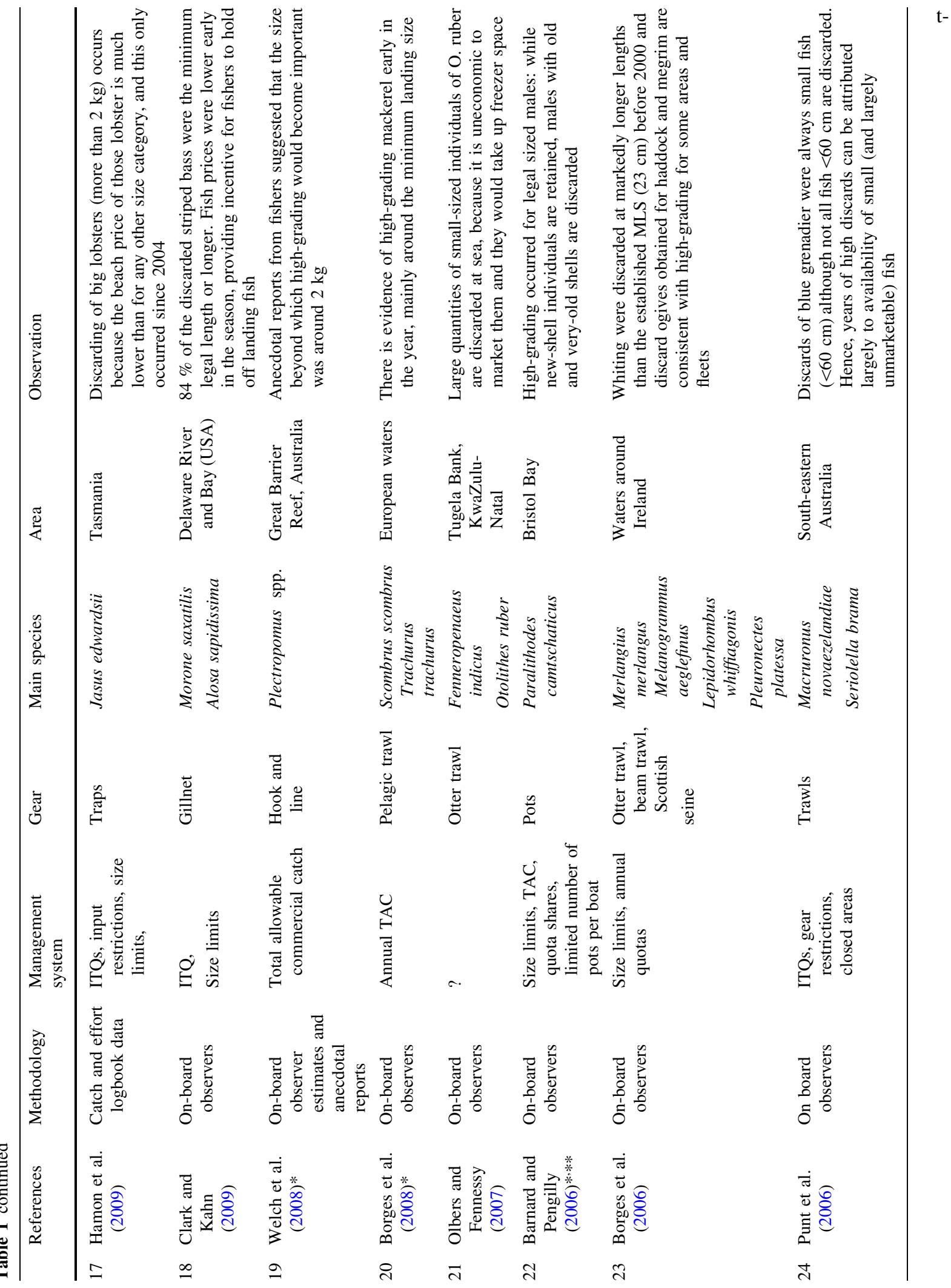




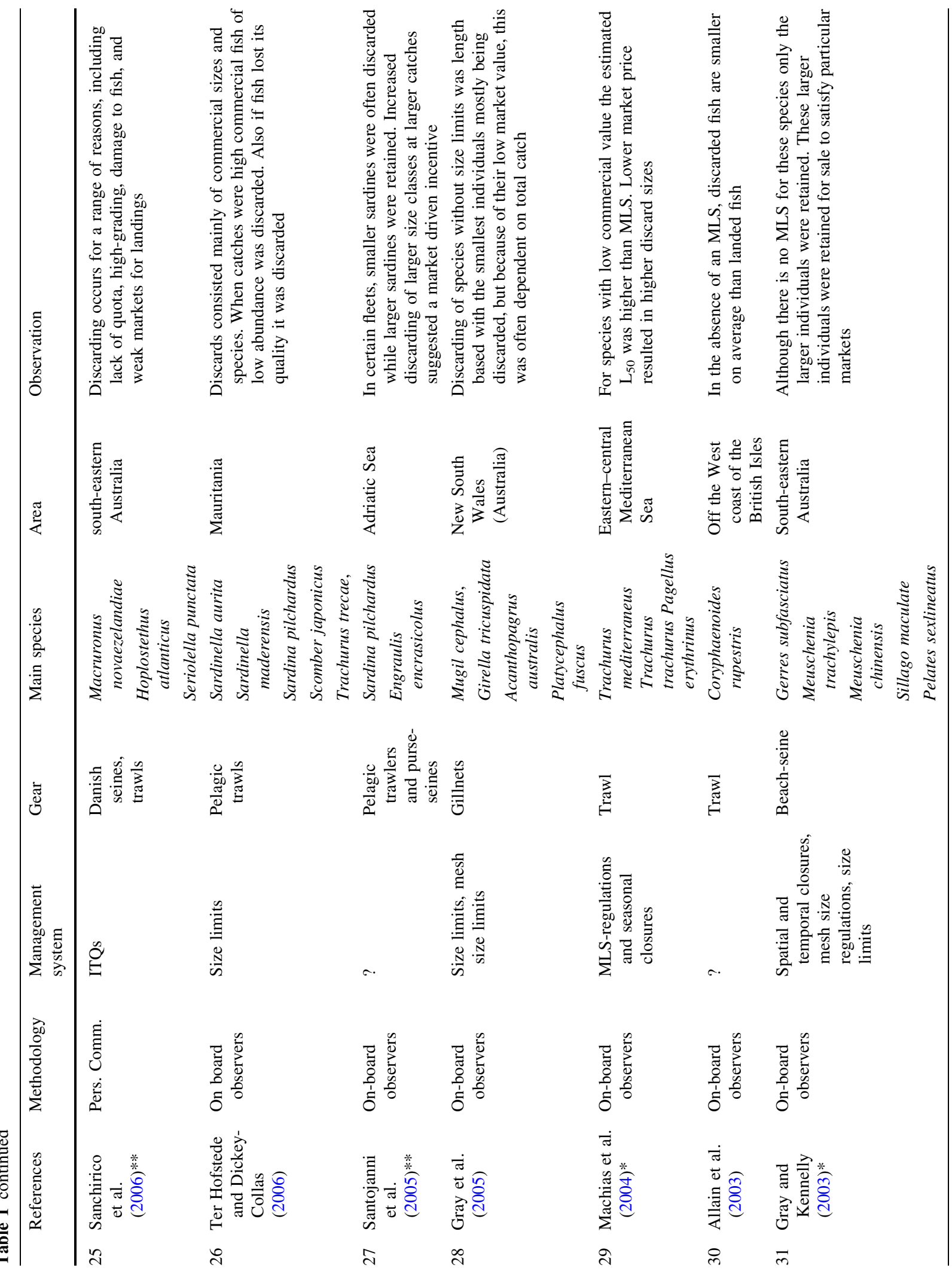




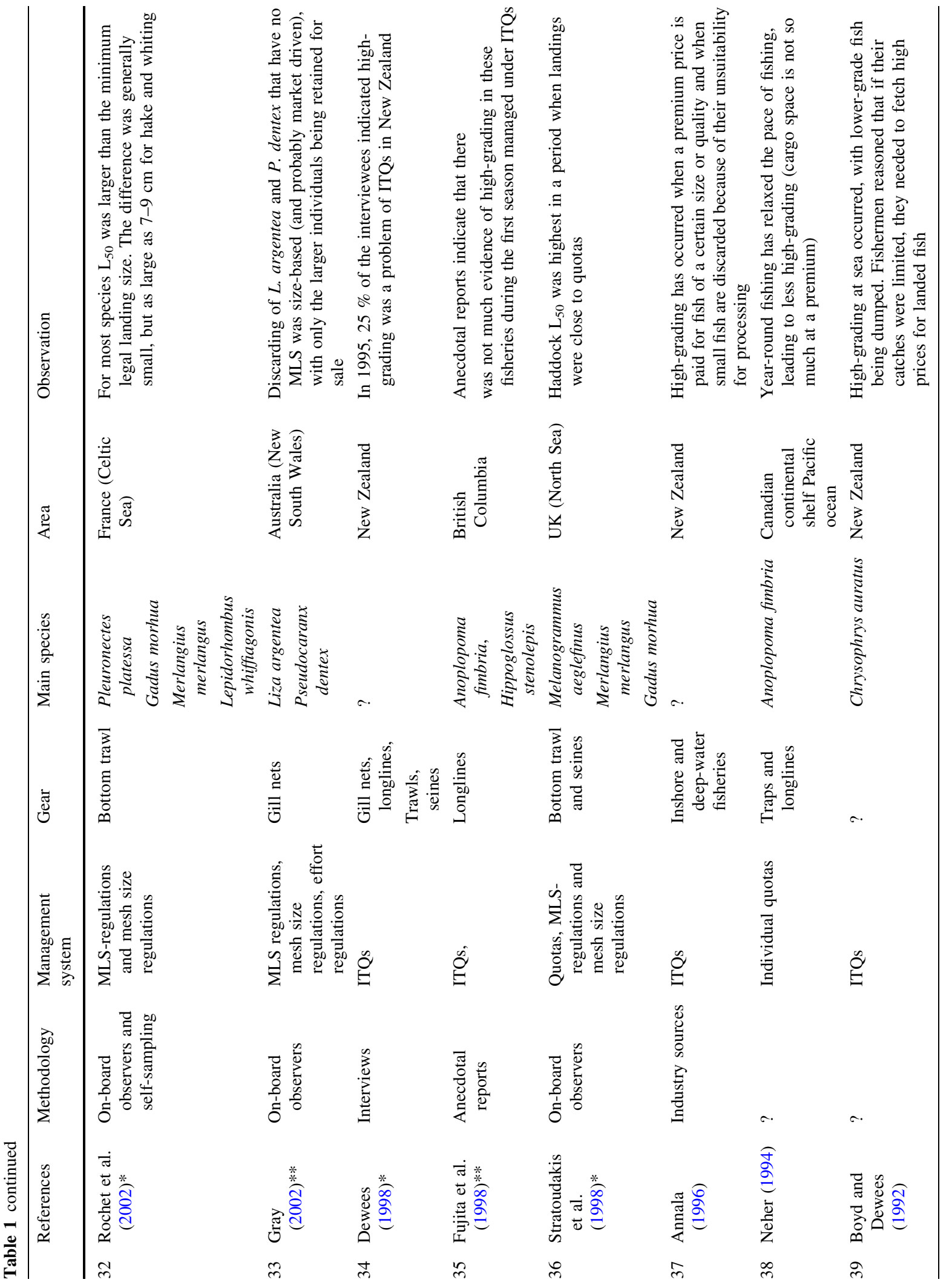




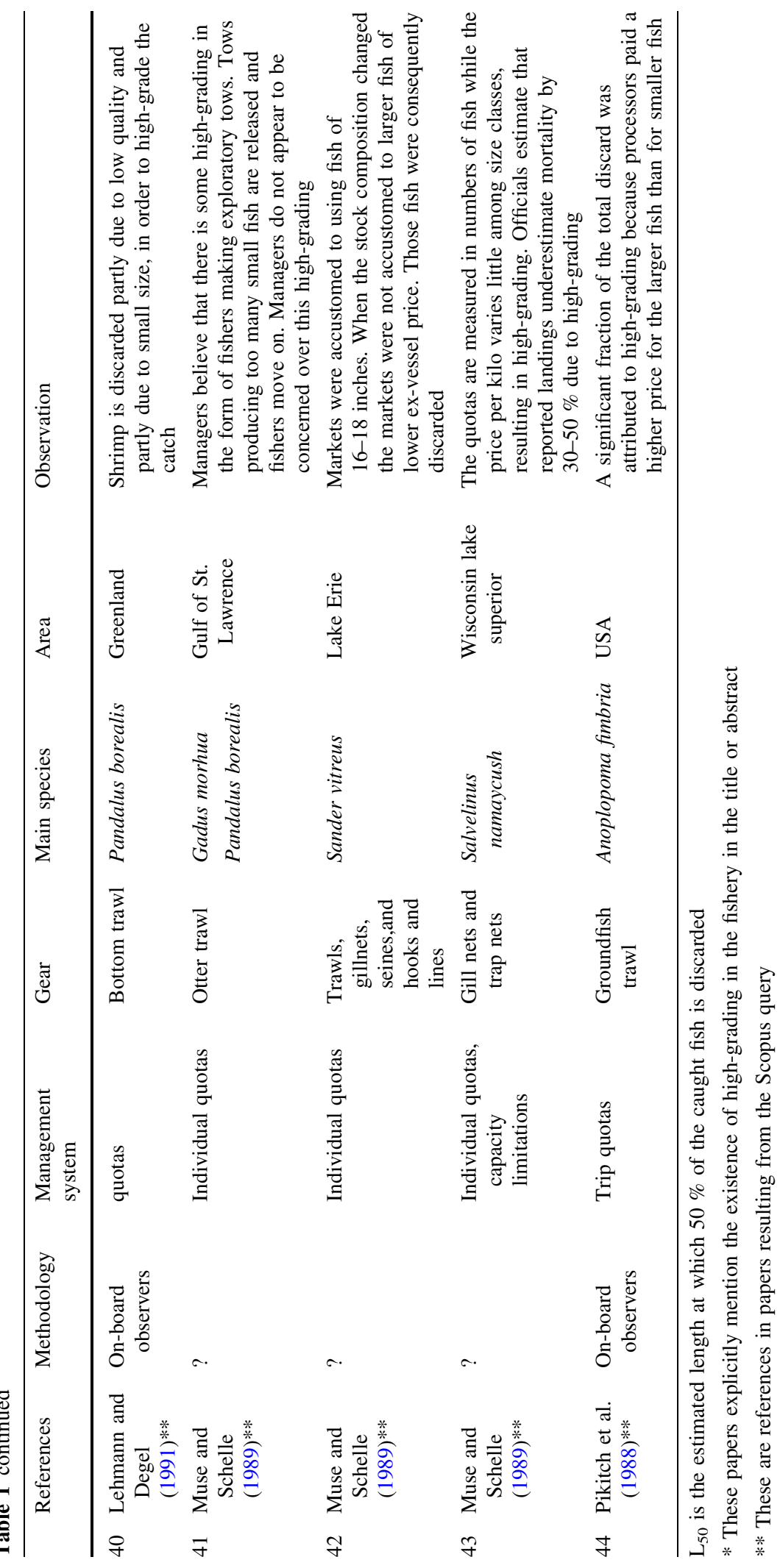


Table 2 Summary of global over-quota discarding papers reviewed

\begin{tabular}{|c|c|c|c|c|c|c|}
\hline References & Methodology & $\begin{array}{l}\text { Management } \\
\text { system }\end{array}$ & Gear & Main species & Area & Observation \\
\hline $\begin{array}{l}\text { Kaplan } \\
\text { et al. } \\
\text { (2014) }\end{array}$ & $?$ & $\begin{array}{l}\text { TAC, bimonthly } \\
\text { cumulative } \\
\text { landings limits, } \\
\text { spatial closures }\end{array}$ & Trawl & $\begin{array}{l}\text { Microstomus } \\
\text { pacificus } \\
\text { Anoplopoma } \\
\text { fimbria }\end{array}$ & $\begin{array}{l}\text { US West } \\
\text { coast }\end{array}$ & $\begin{array}{l}\text { Captains could freely discard species } \\
\text { for which they had exhausted their } \\
\text { landings limit. Successive } \\
\text { tightening of landings limits } \\
\text { caused high regulatory discard } \\
\text { rates }\end{array}$ \\
\hline $\begin{array}{l}\text { Baudron } \\
\text { et al. } \\
(2010)\end{array}$ & $?$ & TACs & $\begin{array}{l}\text { Longline, } \\
\text { pair } \\
\text { trawl }\end{array}$ & $\begin{array}{l}\text { Gadus morhua } \\
\text { Melanogrammus } \\
\text { aeglefinus } \\
\text { Pollachius virens }\end{array}$ & $\begin{array}{l}\text { Faroe } \\
\text { Islands }\end{array}$ & $\begin{array}{l}\text { The TAC system resulted in } \\
\text { extensive discarding when single- } \\
\text { species quotas were filled }\end{array}$ \\
\hline $\begin{array}{l}\text { Clark and } \\
\text { Kahn } \\
(2009)\end{array}$ & $\begin{array}{l}\text { On-board } \\
\text { observers }\end{array}$ & $\begin{array}{l}\text { ITQ, } \\
\text { Size limits }\end{array}$ & Gillnet & $\begin{array}{l}\text { Morone saxatilis } \\
\text { Alosa } \\
\quad \text { sapidissima }\end{array}$ & $\begin{array}{l}\text { Delaware } \\
\text { River } \\
\text { and Bay } \\
\text { (USA) }\end{array}$ & $\begin{array}{l}\text { If the netters reached their striped } \\
\text { bass quota they discarded striped } \\
\text { bass and kept other valuable } \\
\text { species }\end{array}$ \\
\hline $\begin{array}{l}\text { Sanchirico } \\
\text { et al. } \\
\text { (2006) }\end{array}$ & Pers. Comm. & ITQs & $\begin{array}{l}\text { Danish } \\
\text { seines, } \\
\text { trawls }\end{array}$ & $\begin{array}{l}\text { Macruronus } \\
\text { novaezelandiae } \\
\text { Hoplostethus } \\
\text { atlanticus } \\
\text { Seriolella } \\
\text { punctata }\end{array}$ & $\begin{array}{l}\text { South- } \\
\text { eastern } \\
\text { Australia }\end{array}$ & $\begin{array}{l}\text { Discarding occurs for a range of } \\
\text { reasons, including lack of quota, } \\
\text { high-grading, damage to fish, and } \\
\text { weak markets for landings }\end{array}$ \\
\hline $\begin{array}{l}\text { Punt et al. } \\
\text { (2006) }\end{array}$ & $\begin{array}{l}\text { On board } \\
\text { observers }\end{array}$ & $\begin{array}{l}\text { ITQs, gear } \\
\text { restrictions, } \\
\text { closed areas }\end{array}$ & Trawls & $\begin{array}{l}\text { Macruronus } \\
\text { novaezelandiae } \\
\text { Seriolella brama }\end{array}$ & $\begin{array}{l}\text { South- } \\
\text { eastern } \\
\text { Australia }\end{array}$ & $\begin{array}{l}\text { Years of high discards of blue } \\
\text { warehou are related to operators } \\
\text { having insufficient quota to cover } \\
\text { catches }\end{array}$ \\
\hline
\end{tabular}

otal catch due to management, market or physical constraints. In the following sections, we will describe a conceptual model for quantifying high-grading and over-quota discarding.

\section{Simulation model}

In order to gain insight as to the mechanisms inducing high-grading and over-quota discarding behaviour, we used a dynamic-state variable model (DSVM; Houston and McNamara 1999; Clark and Mangel 2000). Dynamic state variable models have been applied in a variety of fisheries to analyse vessel fishing behaviour (Gillis et al. 1995; Poos et al. 2010; Dowling et al. 2012; Batsleer et al. 2013). In such models, the optimal annual strategy of fishing vessels operating in fisheries under individual quotas and in a stochastic environment is evaluated. Our model differs from earlier models in that: (1) it includes size structured fish catches, and (2) ex-vessel price by size class fluctuates over time. The utility function assumes that fishers are profit maximizers. Although other incentives may play a role in decision making, there is empirical evidence for profit as a useful metric of utility (Robinson and Pascoe 1998).

We model bottom trawl fishers targeting three sizestructured fish species (sole, plaice and cod), where catches are divided into market categories based on size (Table 3). The size classes have seasonally variable auction prices (Fig. 1). The size structure and species composition of the catch is thus an important determinant of the value of a catch. The expected catch rates of each species/size class combination is defined by probability distributions that are functions of fishing location and season, reflecting spatial and seasonal variations in abundance. Parameters describing the probability distributions are estimated from historic data.

In the model fishers maximise their annual net revenue $^{1}$ by making weekly decisions on (1) to go fishing or not; (2) fishing location; and (3) how much

\footnotetext{
$\overline{1}$ i.e. the revenue minus variable costs, given that fixed costs do not impact short term decisions.
} 
Table 3 Marketable size classes of the three target species

\begin{tabular}{llll}
\hline Size class & Plaice $(\mathrm{cm})$ & Sole $(\mathrm{cm})$ & Cod $(\mathrm{cm})$ \\
\hline 1 & $>41$ & $>38$ & $>88$ \\
2 & $35-41$ & $33-38$ & $72-88$ \\
3 & $31-35$ & $30-33$ & $55-72$ \\
4 & $27-31$ & $27-30$ & $46-55$ \\
5 & & $24-27$ & $35-46$ \\
\hline
\end{tabular}

to discard given their annual landing quota and restrictions on discarding. A weekly time scale is chosen because most fishing trips last from Monday to catches are discarded) or $2^{31}$ (all catches are landed) for each combination of species and size class. The catches are modelled as a random variable having a negative binomial distribution with a mean $m_{s, n, a, t}$ per area, week, species and size class, and a dispersion parameter per species $r_{s}$. The means and dispersion parameters are estimated from logbook data from the case study fleet. The probability $\lambda_{s, n}\left(l_{s, n}, d_{s, n}, a, t\right)$ of making a landings $l_{s, n}$ of amount $\chi$ is a function of the area choice in a given week, and the discarding decisions such that it has following cumulative distribution function

$$
\begin{aligned}
\lambda_{s, n}\left(l_{s, n} \leq \chi, d_{s, n}, a, t\right) & =f\left(\chi ; d_{s, n}, m_{s, n, a, t}, r_{s}\right) \\
& = \begin{cases}\sum_{l_{s, n}=0}^{\chi}\left(\frac{r_{s}}{r_{s}+m_{s, n, a, t}}\right)^{r_{s}} \frac{\Gamma\left(r_{s}+l_{s, n}\right)}{l_{s, n} ! \Gamma\left(l_{s, n}\right)}\left(\frac{m_{s, n, a, t}}{r_{s}+m_{s, n, a, t}}\right)^{l_{s, n}}, & \text { for } \quad 0 \leq \chi<d_{s, n}\end{cases}
\end{aligned}
$$

Friday in the bottom trawl fishery that serves as a casestudy (Rijnsdorp et al. 2011).

For simplicity we assume that there is one individual quota restricting a single species. In this case we chose plaice given observations of discarding of marketable plaice in the Dutch beam trawl fishery (Poos et al. 2010). Historically, the plaice quota constrained the fishery in the 1990s, leading to changes in the targeting behaviour of the fleet (Quirijns et al. 2008). The cumulative landings in weight of species $s$ of the set of species $S$ and size class $n$ of $N$ size classes is denoted by $L_{s, n}$. The cumulative landings in weight of the quota constrained species, that we define by $s=1$, represents the state of the individual, denoted by $L$ and equal to $\sum_{N} L_{1, n}$.

The landings are determined by the discarding decision and the catches which in turn depend on the spatial and temporal distribution of all size classes within the 3 species. Each week $t$ individuals choose to visit fishing area $a$ and to keep or discard any combination of the size classes caught of the different species. This behaviour is defined by a matrix $d$, of dimension $S$ and $N$. Catches above $d_{\mathrm{s}, \mathrm{n}}$ are discarded. To limit the number of discarding options, the values of $d_{\mathrm{s}, \mathrm{n}}$ are restricted to 0 (all where $\Gamma(\cdot)$ is the gamma function (Press et al. 2002). The optimal strategy in each week of the year, denoted by $t$ depends on the cumulative landings of the quota species. These landings affect the possibility to continue fishing and land fish without exceeding the annual quota. The expected net revenue at the end of the year is linked to the choices in the preceding weeks through a value function between time $t$ and the end of year $T$. The value function represents the maximum expected net revenue to be made between week $t$ and the end of the year $T$ and depends on the state of the individual $L$, the amount of quota $U$ for the quota species, the fine per unit weight for exceeding the quota $F$, and is expressed as $V(L, U, F, t)$. Individuals exceeding their quota get a fine that depends on the quota overshoot. At the end of the year $T$, after all fishing has been completed, the value function $V(L, U, F, T)$ is defined by the fine of overshooting the quota

$\Phi(L, U, F)=\left\{\begin{array}{ll}0, & L \leq U \\ -(L-U) F, & L>U\end{array}\right.$.

For each week before $T$, the expected net revenue is determined by the value function, the weekly gross revenue and the costs of fishing. 


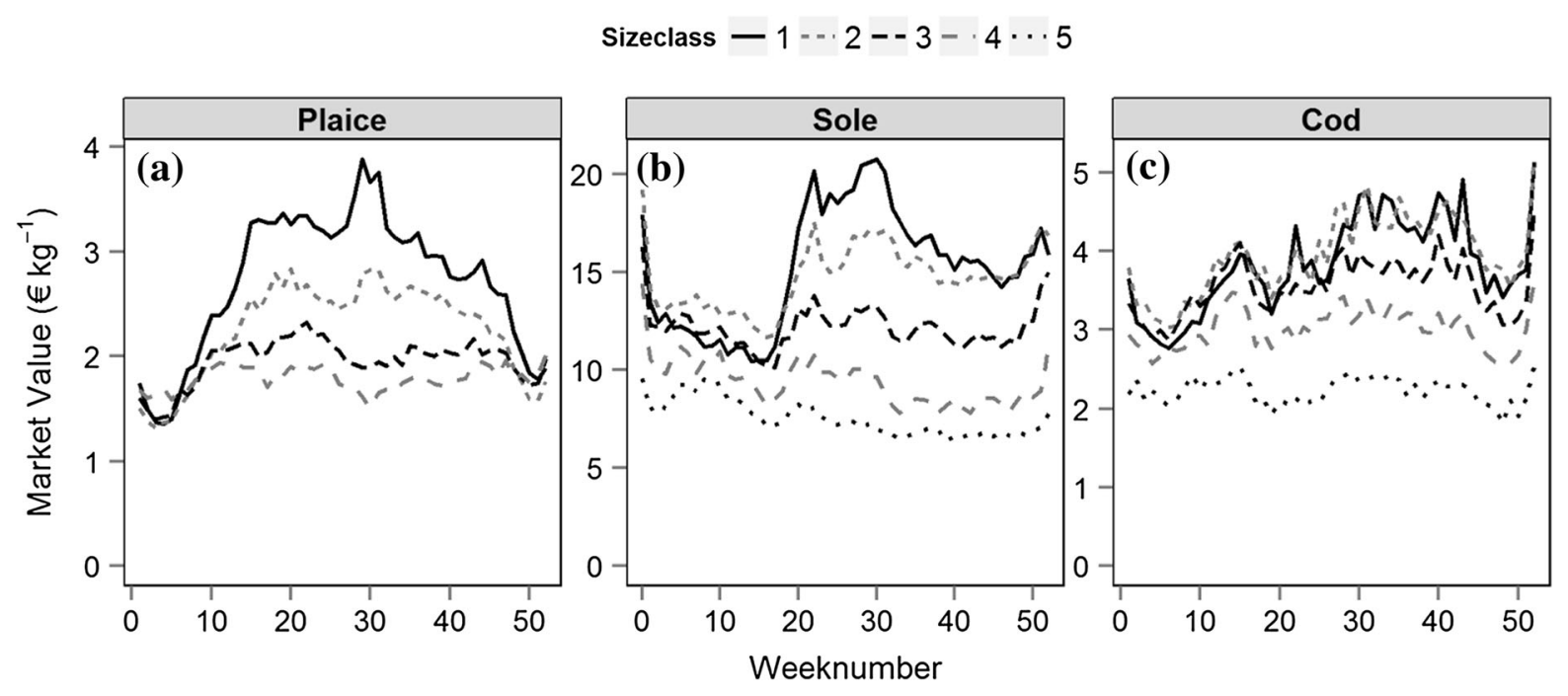

Fig. 1 Seasonal variation in the ex-vessel price of the five size classes of a plaice, $\mathbf{b}$ sole and $\mathbf{c}$ cod. Size classes are ordered from 1large to 5-small (adapted from Rijnsdorp et al. 2012)

For all times $t$ preceding $T$ we use stochastic dynamic programming to find the optimal solution by backward iteration of the net expected revenue $H$ from $t$ to the end of the year considering the choices $a$ and $d$ and the state $L$ at $t$ and optimal choices in subsequent weeks

$$
\begin{aligned}
H(L, U, F, t ; a, d)= & R(a, d, t) * \kappa-C(a) \\
& +\mathbb{E}_{a, d}\left[V\left(L^{\prime}, U, F, t+1\right)\right],
\end{aligned}
$$

where $R(a, d, t)$ is the expected direct contribution of the gross revenue that follows from the sales of fish in a week resulting from choices $a$ and $d$, and the prices of fish in that week $p_{s, n}(t): R(a, d, t)=\sum_{S} \sum_{N} \lambda_{s, n}$ $\left(l_{s, n}, d_{s, n}, a, t\right) * l_{s, n} * p_{s, n}(t)$. The term $\kappa$ represents a factor accounting for the additional revenue obtained from landing marketable species that are not explicitly modelled. The term $C(a)$ represents the variable costs in a week resulting from the choice of fishing area $a$. The term $L^{\prime}$ reflects the change of the state $L$ resulting from the weekly landings for the quota species, $\sum_{N} l_{1, n}$. The term $\mathbb{E}_{a, d}\left[V\left(L^{\prime}, U, F, t+1\right)\right]$ denotes the expected future value taken over all possible states resulting from choices $a$ and $d$. The optimal choice is given by

$V(L, U, F, t)=\max _{a, d}\{H(L, U, F, t ; a, d)\}$.

Hence, starting with $V(L, U, F, T)=\Phi(L, U, F)$ we can iterate backwards in time and find the optimal choice in terms of location and discarding behaviour for all possible states, combining the net revenue obtained from the sale of fish and costs of a fishing trip and the effect of the annual fines when exceeding annual quota.

We explore high-grading and over-quota discarding decisions of conventional beam trawlers under a range of individual plaice quota (100-800 tonnes year ${ }^{-1}$ ).

\section{Case study data}

Marketable catch and effort data by fishing trip are obtained from logbooks and individual sale slips for large Dutch beam trawl mixed fishery $(>1500 \mathrm{hp})$. Restrictive TACs in recent years may bias port-based catch rate observations of marketable fish because of over-quota discarding and high-grading (Rijnsdorp et al. 2008; Poos et al. 2010). Therefore, log book data from 1970 to 1974 are used, a period where there were minimum mesh and landing sizes, but no TACs (Daan 1997). TACs were introduced only in 1975 for this fishery (Salz 1996). The data are collected on a trip by trip basis and include the landed weight of marketable fish by species and size category, fishing ground (ICES rectangle, ca. $30 \times 30$ nautical miles), fishing effort (hours fished), fishing gear, vessel length, and engine power. Data for plaice, sole and cod are analysed. 


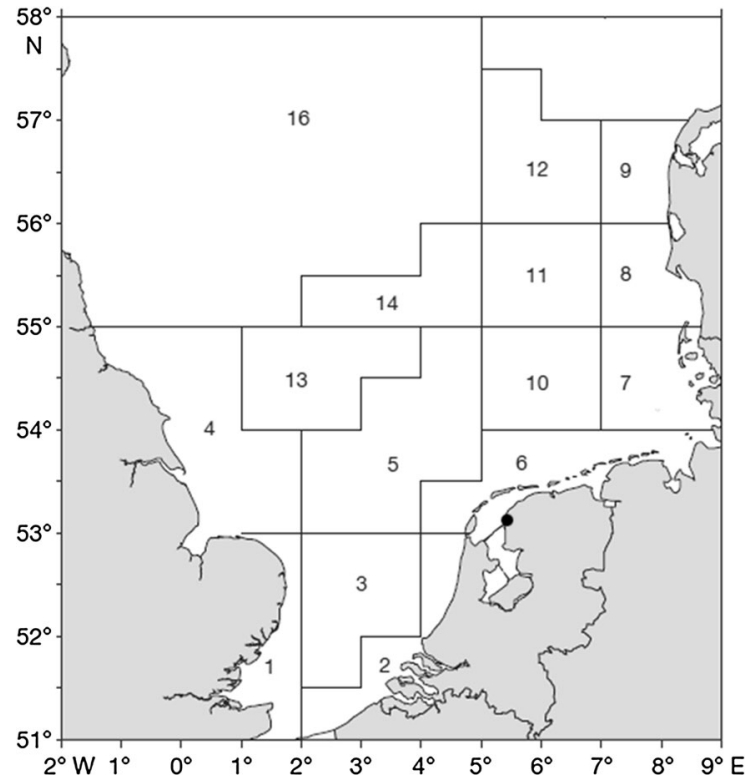

Fig. 2 Fishing areas, black point indicates the location of the fishing harbour used in the model

Fishing areas are defined by aggregating ICES rectangles, similar to (Rijnsdorp et al. 2012; Fig. 2). The large Dutch beam trawlers are prohibited from fishing in the Plaice Box (areas 6-9) and the 12 nautical mile zones (areas 1 and 2). These areas are excluded from further analysis. Fishing effort is determined by summing the fishing time and the travel time per week. The fishing time for large trawlers is estimated at $65 \mathrm{~h}$ per week based on the effort dataset. Travel time is calculated by taking the distance from the harbour of departure to each of the fishing grounds and assuming a steaming speed of 12 nautical miles $\mathrm{h}^{-1}$ (Poos et al. 2013).

\section{Trawl catch rates}

Seasonal catch rates per fishing area for the different size classes of plaice, sole, and cod in the beam trawl fleet are described using generalized additive models (GAM, Wood 2006). Catch rates are modelled using the weight of the catches $(\mathrm{kg})$ from the logbooks per size class per fishing trip as a response variable while effort (h) is used as offset variable (Wood 2006). By using a negative binomial GAM with a logarithmic link function we allow over-dispersed data and zeroobservations (Wood 2006; Zuur et al. 2009). The model to estimate catch by size class $n$ and area $a$ per week is applied to the data per species $s$ :

$$
\begin{aligned}
m_{s, n, a, t}= & a+\text { gear }+f_{1}(n, t \mid a)+\log (\text { engine power }) \\
& +f_{2}(\text { sweek }, n)+\text { offset }(\log (\text { effort }))
\end{aligned}
$$

where $f_{1}$ and $f_{2}$ are smooth functions based on a tensor product smoother (Wood 2006). The tensor product smoother $f_{1}(n, t \mid a)$ is based on a cubic regression spline for size class and a cyclic cubic regression spline for week by area. The cubic regression spline for week by area results in equal values and slopes at the beginning and end of the year (Wood 2006). The maximum degrees of freedom for both smoothing terms is limited $(\mathrm{k}=4)$ to prevent over-fitting. The covariate engine power is the log-transformed horse power and is included because of its influence on the catch efficiency. The covariate gear is included to differentiate the catch efficiencies between the beam and otter trawl. The covariate sweek within the second smoothing term $f_{2}$ (sweek, $n$ ) is week number since the start of the data collection (1 January 1970) and captures the gradual changes in biomass for each size class over time as a result of recruitment and mortality. In addition to the estimates of the mean catches $m_{s, n, a, t}$ the model also returns the estimated dispersion parameter per species $r_{s}$. All analyses were done using the $\mathrm{R}$ statistical program (version 2.12.1; R Core Development Team 2013). The "mgcv 1.7-29" package was used for the GAM model for trawl catch rates (Wood 2011).

The GAM model is used to estimate the spatial and temporal patterns in catch rates $\left(\mathrm{kg} \mathrm{week}^{-1}\right)$ for each size class of each target species in the period 1970-1974. To obtain values representative for the time period in which the economic data is collected, the predictions are rescaled with a factor calculated by dividing the mean of the absolute values of the spawning stock biomass (SSB) of 1970-1979 by the mean of the absolute values of the SSB of the past 10 years (2004-2013).

\section{Economic data}

The three species modelled represent $82 \%$ of the gross revenue of the Dutch beam trawl fleet. Mean weekly market values for the marketable size classes are calculated from sale slip data from 2003 to 2007 (Fig. 1). The fine for overshooting the individual quota is set to $320 € \mathrm{~kg}^{-1}$. Such a high fine ensures full compliance to the individual quotas in the model. Costs of discarding in terms of additional sorting time are assumed to be negligible. 
Table 4 Variable costs of the beam trawl used in the simulation

\begin{tabular}{lll}
\hline Variable fishing costs & Value & Units \\
\hline Fuel costs & 6400 & $€$ day $^{-1}$ \\
Gear maintenance & 347 & $€$ day $^{-1}$ \\
Landing costs & 0.24 & $€ \mathrm{~kg}^{-1}$ \\
Employment costs & 33 & $\%$ \\
Other variable costs & 0.05 & \\
\hline
\end{tabular}

Information on the cost structure of large beam trawl vessels (2008-2010) is obtained from LEI (Agricultural Economic Research Institute). The variable costs represent about $75-80 \%$ of the total annual costs and include fuel costs, gear maintenance costs, cost of handling and transportation of landings, crew shares and other variable costs, such as auction and harbour fees. Fuel costs depend on effort and fuel price and is estimated to be approximately $€ 6400$ day $^{-1}$ (van Marlen et al. 2014). Gear maintenance cost is assumed proportional to fishing effort, landing costs proportional to the total weight landed, and other variable costs proportional to the gross revenue. Crew shares are predominantly determined by an agreement between the owner and his crew. Crew share is calculated after fuel, handling and transportation costs are deducted from the gross revenue. Values used for variable costs in the simulation model are presented in Table 4 .

\section{Results}

Trawl catch rates

The input data of the simulation model consists of the estimates of the weekly catch rates for the different size classes of plaice, sole and cod. Distinct seasonal patterns between the different size classes for each of the three target species are observed (Fig. 3). Large plaice ( $>31 \mathrm{~cm}$, size classes 1,2 and 3 ) exhibit a

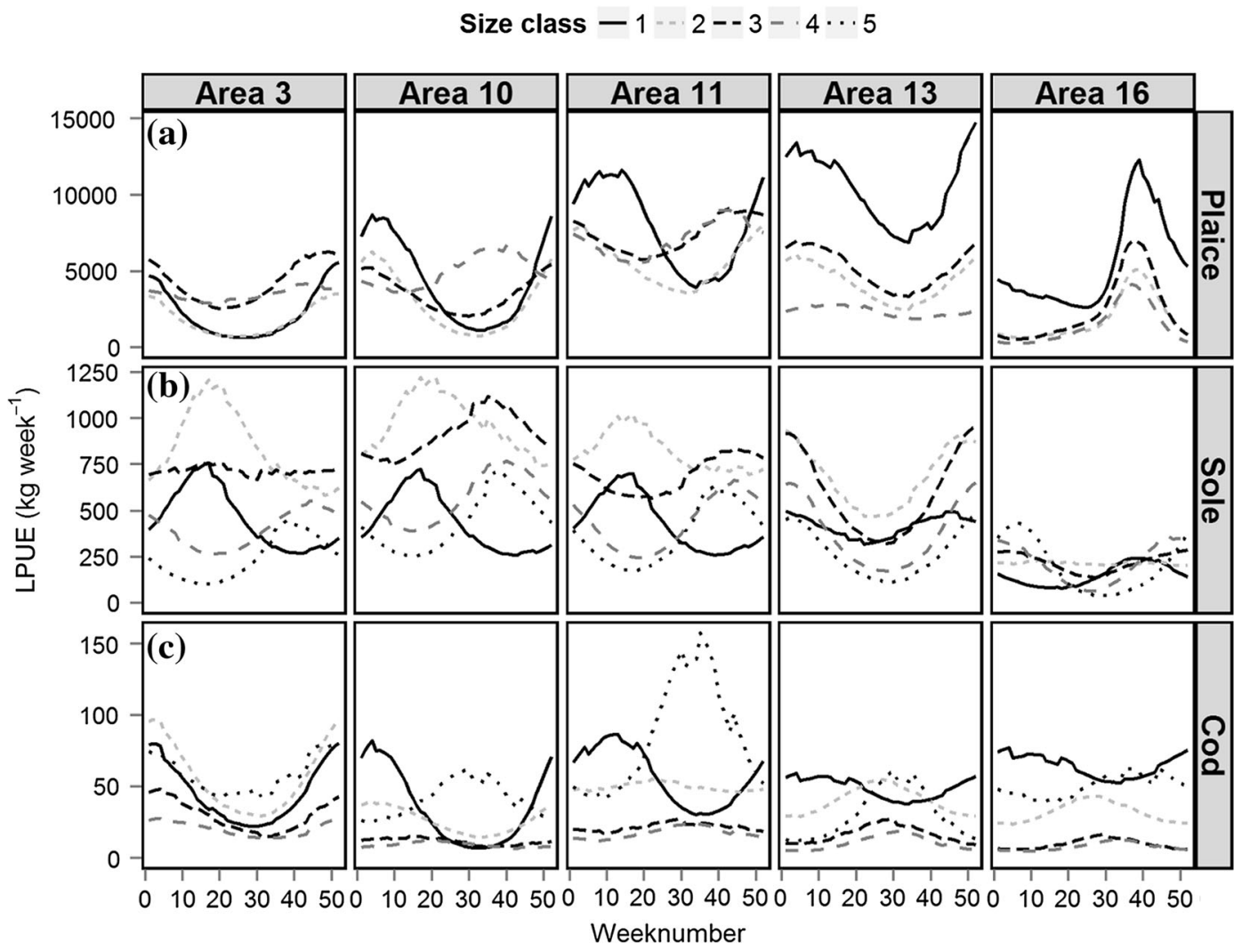

Fig. 3 Seasonal variations in the landings per unit of effort (LPUE $\mathrm{kg} \mathrm{week}{ }^{-1}$ ) of the size classes of a plaice, $\mathbf{b}$ sole and $\mathbf{c}$ cod. Size classes are ordered from 1 -large to 5 - small 


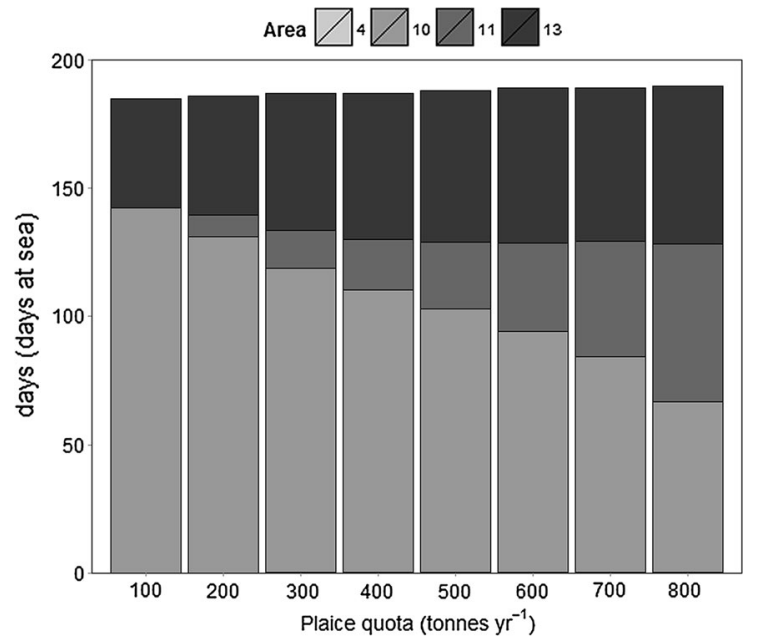

Fig. 4 Annual fishing effort (days at sea) and fishing areas selected as a function of the plaice quota for a beam trawler under a management regime where discarding is allowed. Area 4 is only selected for quotas $>300$ tonnes year $^{-1}$. The effort allocated to this area is extremely limited. The majority of effort is allocated to areas 10,11 , and 13

similar seasonal distribution in most areas with low catch rates during spring and summer and high catch rates in the winter months. The smallest marketable size class $(27-31 \mathrm{~cm}$, size class 4$)$ exhibits the opposite pattern with higher catch rates in spring and summer and lower catch rates in winter months. In addition, the catchability of large plaice appears to be higher in the more central and northern areas of the North Sea (e.g. area 13, Southern Dogger Bank) compared to the more coastal areas (e.g. area 3, Southern Bight).

For sole, the catch rates of the larger size classes ( $>33 \mathrm{~cm}$, size class 1 and 2) peak in winter and early spring, while the smaller size classes (size classes 3, 4, and 5) show a seasonal pattern, with a peak in summer and early autumn similar to that for smaller plaice. Sole catch rates are highest in the North Sea areas closer to the coast such as the Southern and German Bight (areas 3 and 10). Within the more central and northern areas of the North Sea catch rates are lower.

The highest catch rates of cod (all size classes) within the coastal areas (area 3, southern Bight) are observed in December and January. A different pattern emerges for the offshore areas such as the German Bight (area 10 and 11) where the catch rates of the smallest size class $(35-46 \mathrm{~cm})$ peak in late spring and summer while large cod $(88+\mathrm{cm})$ catch rates peak in winter and early spring. These patterns although still present, level off in most northern areas such as the Dogger Bank and Central North Sea (area 13 and 16). Catch rates of intermediate size classes (3 and 4) of cod are consistently low throughout the year for all areas.

\section{Simulation model}

The catch rates for the different size classes of plaice, sole, and cod are used as input to the model, together with the cost structure for the different choices. The model is run for individual plaice quotas ranging from 100 to 800 tonnes. No publicly available information exists on the amount of individual quotas per vessel, hence we used the 2013 plaice landings of the fishing vessels of the Dutch harbor Urk as a proxy for individual quotas. The landings ranged between 160 and 795 tonnes per vessel, with a median of 629 tonnes. Runs are used to evaluate the effects of different landing ITQ levels on effort allocation, and discarding behavior.

\section{Effort allocation}

Increasing individual quota for the limiting species results in a very small increase in overall fishing effort per vessel. However, there is a substantial reallocation of fishing effort over the fishing areas (Fig. 4). A low individual quota results in a concentration of fishing effort in the German Bight (area 10) which is one of the areas open for fishing close to the harbor. As individual quotas increase, more effort is allocated to areas 11 and 13 at the expense of effort in area 10. This shift to northern fishing grounds can be explained by the availability of large plaice in those areas.

\section{Catches of marketable fish}

The marketable catches comprise landings and discards (over-quota and high-graded fish). Landings are perfectly controlled by the individual quota because fines for overshooting quota are much higher than the value of the extra catch and the risk of getting fined for overshooting is $100 \%$ in the model. Discarding of marketable plaice occurs in two different ways: overquota discarding, when quota is exhausted and discarding occurs for all size classes, and highgrading, when fishers have quota available and discard 


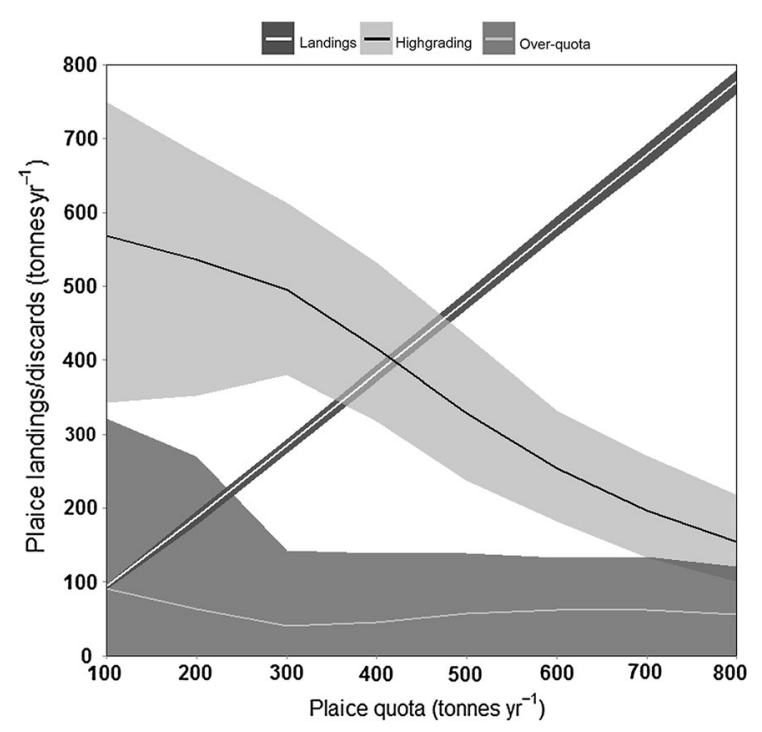

Fig. 5 Landings and discards (tonnes year ${ }^{-1}$ ) of a beam trawler as a function of the plaice quota. Discards are distinguished between high-grading and over-quota discarding

certain size classes. The model results indicate that over-quota discarding is largely unaffected by the amount of quota available, while high-grading increases with a decreasing quota (Fig. 5).

All over-quota discarding occurs at the end of the year (Fig. 6). When more quota is available, fishers take more time to reach their quota limit and therefore over-quota discarding occurs later in the year. In our case study system, there is substantial seasonal variation in the prices of the different size classes for the limiting species. At the beginning of the year prices for all size classes are lower than later in the year. In addition, larger fish generally fetch higher prices than smaller fish, except for the beginning of the year when the opposite is observed. As a result of the seasonal variability in prices, the highest amount of fish being high-graded is in the first weeks and at the end of the year when fish prices are low (Fig. 6). With low quota fishers will high-grade year-round. An increase in quota systematically reduces the occurrence of high-grading throughout the year. The decrease in high-grading first occurs in the middle of the year (price of fish is highest) and then at the end of the year.

The size distribution of the catches, landings and discards of marketable plaice is influenced by the amount of quota (Fig. 7). Each of these distributions depends on the allocation of effort to areas or weeks characterised by different size composition and the discarding choices made by the individual skippers. At high quota, there are relatively few discards of the smallest size classes. Reductions in quotas result in an increasing amount of small fish being high-graded. The relationship between the discarding of small fish and the quota is far from linear and results from the

\section{Landings — High-grading $\cdot-$. Over-quota}
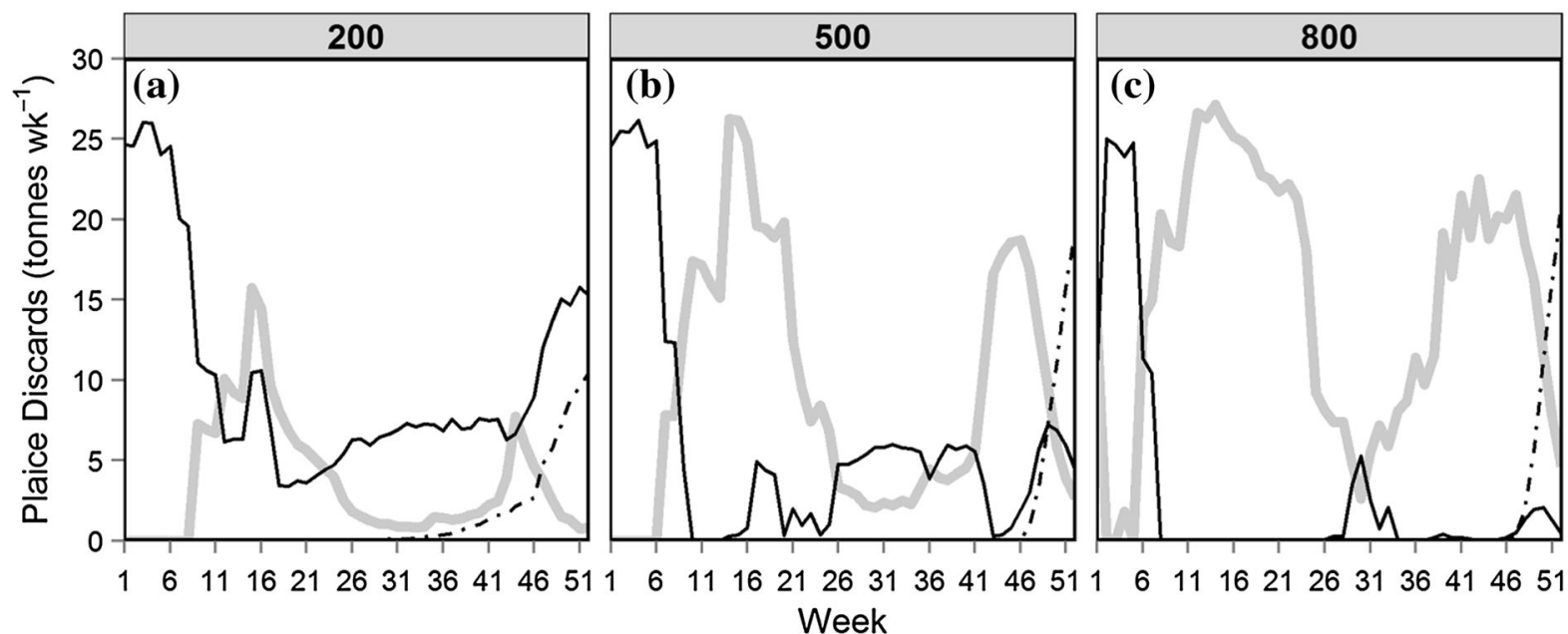

Fig. 6 Weekly landings and discards for a beam trawler at a plaice quota of a 200, b 500 and $\mathbf{c} 800$ tonnes year $^{-1}$. High-grading and over-quota discarding are depicted separately 
Size-Class $\square 1 \square 2 \square 3 \square 4$
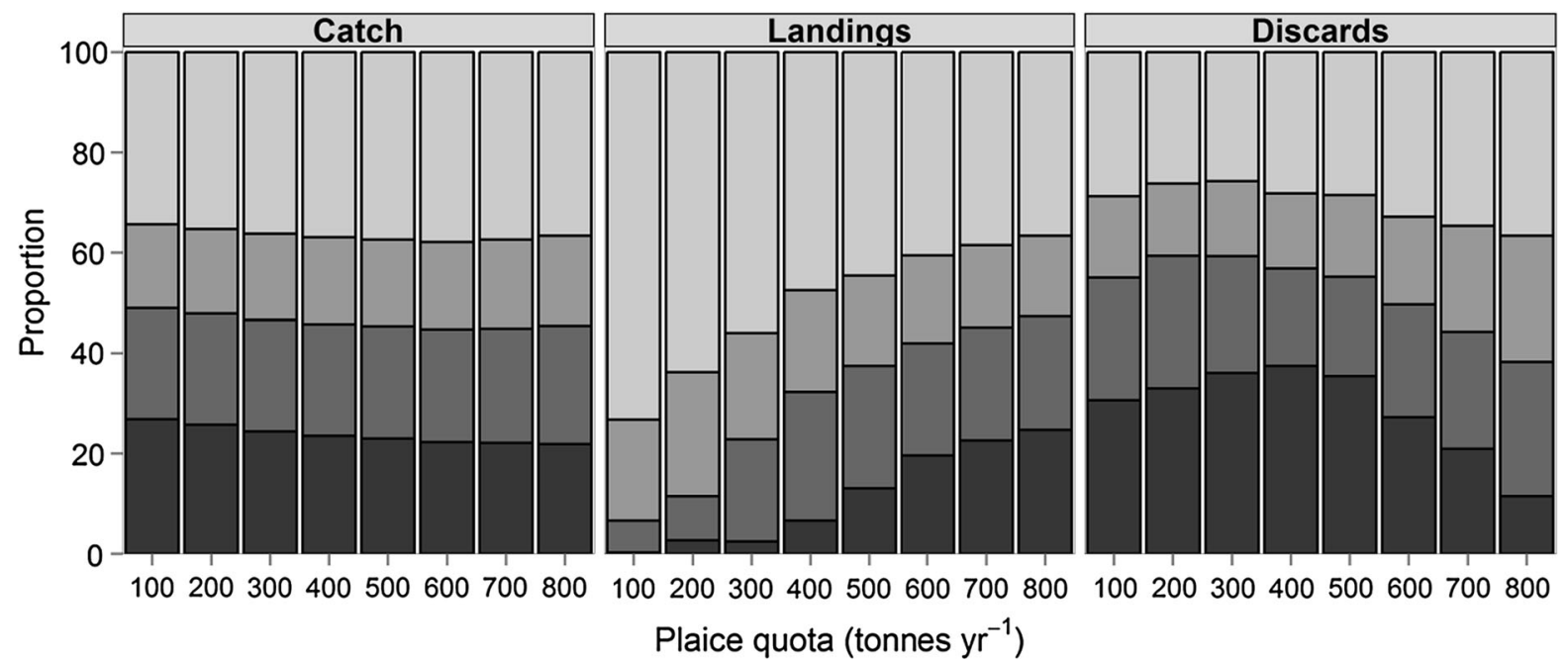

100200300400500600700800

Fig. 7 Proportion of marketable size classes in the catch, landings and discards for a beam trawler as a function of plaice quota

interplay between the seasonal differences in availability and ex-vessel price of the different market categories.

\section{Discussion}

Having started with a broad query which produced 336 papers, our review of literature resulted in 44 papers describing observations of high-grading. Our findings that only 44 papers contained high-grading observations corroborates Boyd and Dewees (1992), who stated that even if high-grading is expected, it is difficult to detect and prove: on board observers may influence the fishing behaviour of skippers and reduce the probability of detection (Liggins et al. 1997; Benoît and Allard 2009). Despite this problem, the positive reports reviewed shows that high-grading occurs worldwide in both pelagic and demersal fisheries, in fisheries with and without ITQs, in commercial and recreational fisheries, and in singlespecies and mixed fisheries. In all these fisheries, we expect differences in utility among different size classes of fish (Zimmermann and Heino 2013) or among different periods within the quota planning horizon (Rijnsdorp et al. 2012), being one of the prerequisites for high-grading (Branch et al. 2006). We expect the incentive to high-grade to depend on the price differential among the different size classes (Kingsley 2002).

Most of the fisheries in which high-grading was observed are mixed fisheries managed under individual catch quota systems. This is not surprising given that individual quotas allow individuals to maximise the economic return on their quota by high-grading the cheaper parts of the catch and increasing the average return per unit quota (Gillis et al. 1995; Squires and Kirkley 1995). These fisheries allow individual fishers to plan the use of their quota, being it on an annual, trip or other time-period. The mixed nature of the fishery allows income from a fishery even if parts of the limiting quota species are discarded. Meanwhile, discarding of undersized fish may also occur in mixed fisheries if minimum size limits of different species and mesh size regulations do not match (Daan 1997).

Our review suggests that high-grading often occurs because of quota constraints. For example, in the North Sea, megrim (Lepidorhombus whiffiagonis) is high-graded and the likelihood of this species being discarded decreases significantly with increasing quota (Macdonald et al. 2014). Likewise, the amount of high-grading for cod in the North Sea by Belgian fishers decreased nearly linearly with trip quota (Depestele et al. 2011). Elsewhere, high-grading is suggested as a problem of limiting individual quota (Dewees 1989, 1998). In a few cases, market 
conditions were pinpointed as the important driving force for high-grading. This difference in the frequency of occurrence could suggest that fisheries strive to find markets for as much of their catch as possible.

We found substantially fewer papers that described observations of over-quota discarding than those describing observations of high-grading. This could be due to several reasons. First, high-grading can occur for reasons of constraining quota or market conditions, while over-quota discarding only occurs because of limiting quota. Second, we decided to only include papers where the wording unequivocally indicated that discarding occurred after quotas were depleted. Finally, we expect that fishers will use price differences in market classes and fishing seasons to high-grade their catches, rather than discard the entire catch including the high-valued market categories at the end of the year.

The dynamic state variable model simulates a mixed fishery under individual quota constraints with a price differential among different size classes. Seasonal and size variations of the prices result in the discarding of specific size classes if quota are restrictive. Importantly, the model results indicate that the amount of high-grading is sensitive to the amount of quota, while over-quota discarding is almost constant irrespective of the quota level. The reason for this difference is that high-grading is the result of fishers planning their use of available quota. Overquota discarding is the result of the stochastic nature of the catches which prevents fishers from planning their catches perfectly. Hence, we hypothesize that the amount of over quota discarding is a function of the variability in the catch rates. In an environment with price differences among size classes or seasons, overquota discarding will decrease with decreasing uncertainty in catch rates.

By incorporating size structure in the resources, seasonally variable catch rates and fish prices we have improved the ability to explore the consequences of quota management on the discarding of marketable size classes compared to earlier studies (e.g. Gillis et al. 1995; Poos et al. 2010; Batsleer et al. 2013). Some simplifying assumptions, however, still remain. In our study, six assumptions are relevant. First, we assume that individual fishers maximize their economic performance while fully complying with management regulations. Non-compliance to quota regulations would result in a lower amount of highgrading and over-quota discarding if fish are landed illegally. Second, the model ignores quota leasing. Such quota leasing could reduce high-grading and over-quota discarding if fishers who are forced to discard can buy quota from vessels with excess quota because of low catch rates. This quota leasing would not occur in situations with low quota when all vessels are constrained by the quota, or in situations with high quota when no vessels are constrained. Third, the model does not incorporate any frequency or density dependent effects, such as exploitation and interference competition, which may negatively affect catch rates (Rijnsdorp et al. 2000; Gillis 2003), or price formation (as in e.g. Dowling et al. 2012). Fourth, only three target species (i.e. plaice, sole and cod) are included in our model of which only plaice has a catch quota affecting the behavior of a fisher while in reality, sole and cod are also managed by quota. In addition, location choice may also be affected by the availability of other components of the mixed fishery such as turbot (Scophthalmus maxima) and brill (Scophthalmus rhombus; Gillis et al. 2008). Fifth, we assume that the hold capacity does not constrain the landings within a fishing trip. Finally, the model assumes that the proportional catch of different size categories is fixed within each area and season. In reality, the fishers may have the additional behavioral flexibility of changing the proportional catches of different size categories by changing the mesh size of the gear. However, in our case study the effect of changing the mesh size is substantially different for the different species. Increasing the mesh size has a much stronger effect on the catches of the more valuable sole than it has for plaice, because of the difference in shape between the two species (Van Beek et al. 1983).

Our model shows that fishers can respond to changes in individual quota by reallocation of effort and discarding part of their marketable catch. These results are in line with previous studies showing the adaptability of fishers in a mixed fishery to reallocate effort in space and time thereby optimizing their catch composition relative to the size of the quota (Poos et al. 2010; Batsleer et al. 2013). Our model results indicate that substantial high-grading may occur at the beginning of the year, long before quota are exhausted as a result of seasonal variation in the price of plaice. During the spawning period, the price of the larger size classes of plaice is relatively low as compared to the 
smaller size classes due to the presence of a large gonad and a lower meat quality of spawning fish (van Overzee and Rijnsdorp 2015). High-grading also occurs during other parts of the year, in particular in late summer and autumn when a new year class recruits to the fishery and the high catch rate of the smallest size class coincide with a relatively low price compared to the larger size classes. The amount of over-quota discarding is more limited and by definition concentrated at the end of the year. This overquota discarding is the result of the uncertainty in the catch rates, preventing individuals from optimizing the use of quota by high-grading alone.

In the model, individual landing quotas are strictly enforced by means of high fines while high-grading is allowed. In reality, high-grading is prohibited in the North Sea since 2009. To test whether a ban on highgrading can be enforced effectively, we estimated the number of observed infringements from the campaign results of the joint deployment plan of the European Fisheries Control Agency (EFCA). All campaign results in terms of number of on board inspections, number of infringements of fisheries conservation measures, and the nature of the infringement are published on the EFCA website. Based on the reports from the period 2009-2012, it seems that inspections in the North Sea rarely detect high-grading: The 3000 inspections carried out, recorded approximately 350 infringements, of which only one was related to highgrading (EFCA 2014). Although this could indicate high-grading in these fisheries occurs rarely, we infer that it reflects the difficulty of detection because (1) high-grading can only be detected by fishery inspectors when fishers are caught in action and (2) the time needed to process the catch on board is relatively short.

To our knowledge, our study is the first to model discarding of marketable fish while explicitly distinguishing between high-grading and over-quota discarding. Given the difficulties in obtaining reliable estimates of the amount of marketable fish that is discarded, modelling studies can provide the urgently required insight as to the quantity, the age and size structure as well as the conditions when this may be expected. This insight may guide inspection agencies to manage their inspection effort. More importantly, the insight as to the quantity as well as the size or agestructure of the discarded catch will allow fisheries scientists to explore the accuracy of their assessment of the stock (Harley et al. 2000; Dickey-Collas et al. 2007; Heery and Berkson 2009; Pawlowski and Lorance 2009) and the quality of the scientific advice (Daan 1997; Rijnsdorp et al. 2007; Ulrich et al. 2011).

Acknowledgments This research was supported by the European Community's Seventh Framework Programme (FP7/2007-2013) under Grant Agreement No. 266445 for the VECTORS project and Grant Agreement No. 289257 for the MYFISH project. We thank the two anonymous reviewers whose comments helped improve and clarify this manuscript.

Open Access This article is distributed under the terms of the Creative Commons Attribution 4.0 International License (http:// creativecommons.org/licenses/by/4.0/), which permits unrestricted use, distribution, and reproduction in any medium, provided you give appropriate credit to the original author(s) and the source, provide a link to the Creative Commons license, and indicate if changes were made.

\section{References}

Aarts G, Poos JJ (2009) Comprehensive discard reconstruction and abundance estimation using flexible selectivity functions. ICES J Mar Sci 66:763-771

Allain V, Biseau A, Kergoat B (2003) Preliminary estimates of French deepwater fishery discards in the Northeast Atlantic Ocean. Fish Res 60:185-192

Anderson LG (1994) An economic analysis of highgrading in ITQ fisheries regulation programs. Mar Resour Econ 9:209-226

Annala JH (1996) New Zealand's ITQ system: have the first eight years been a success or a failure? Rev Fish Biol Fish 6:43-62

Arnason R (1993) The Icelandic individual transferable quota system: a descriptive account. Mar Resour Econ 8:201-218

Baelde P (2001) Fishers' description of changes in fishing gear and fishing practices in the Australian South East Trawl Fishery. Mar Freshw Res 52:411-417

Barnard DR, Pengilly D (2006) Estimates of red king crab bycatch during the 2005/2006 Bristol Bay red king crab fishery with comparisons to the 1999-2004 seasons. Alaska Department of Fish and Game. Fishery data series no. 06-23. Anchorage

Batsleer J, Poos JJ, Marchal P, Vermard Y, Rijnsdorp AD (2013) Mixed fisheries management: protecting the weakest link. Mar Ecol Prog Ser 479:177-190

Baudron A, Ulrich C, Nielsen JR, Boje J (2010) Comparative evaluation of a mixed-fisheries effort-management system based on the Faroe Islands example. ICES J Mar Sci 67:1036-1050

Benoît HP, Allard J (2009) Can the data from at-sea observer surveys be used to make general inferences about catch composition and discards? Can J Fish Aquat Sci 66:2025-2039

Bochenek EA, Powell EN, DePersenaire J (2012) Recall bias in recreational summer flounder party boat trips and angler 
preferences to new approaches to bag and size limits. Fish Sci 78:1-14

Bök TD, Goktürk D, Kahraman AE (2011) Bycatch in 36 and $40 \mathrm{~mm}$ PA Turkish twin rigged beam trawl codends. Afr J Biotechnol 10:7294-7302

Borges L, Zuur AF, Rogan E, Officer R (2006) Modelling discard ogives from Irish demersal fisheries. ICES J Mar Sci 63:1086-1095

Borges L, Van Keeken OA, Van Helmond ATM, Couperus B, Dickey-Collas M (2008) What do pelagic freezer-trawlers discard? ICES J Mar Sci 65:605-611

Boyd RO, Dewees CM (1992) Putting theory into practice: individual transferable quotas in New Zealand's fisheries. Soc Nat Resour 5:179-198

Branch TA (2009) How do individual transferable quotas affect marine ecosystems? Fish Fish 10:39-57

Branch TA, Hilborn R (2008) Matching catches to quotas in a multispecies trawl fishery: targeting and avoidance behavior under individual transferable quotas. Can J Fish Aquat Sci 65:1435-1446

Branch TA, Rutherford K, Hilborn R (2006) Replacing trip limits with individual transferable quotas: implications for discarding. Mar Policy 30:281-292

Brewer JF (2011) Paper fish and policy conflict: catch shares and ecosystem-based management in Maine's groundfishery. Ecol Soc 16:15

Campbell MJ, McLennan MF, Sumpton WD (2014) Short-term survival of discarded pearl perch (Glaucosoma scapulare Ramsay, 1881) caught by hook-and-line in Queensland, Australia. Fish Res 151:206-212

Catchpole TL, Feekings JP, Madsen N, Palialexis A, Vassilopoulou V, Valeiras J, Garcia T, Nikolic N, Rochet M-J (2014) Using inferred drivers of discarding behaviour to evaluate discard mitigation measures. ICES J Mar Sci 71:1277-1285

Cetinić P, Škeljo F, Ferri J (2011) Discards of the commercial boat seine fisheries on Posidonia oceanica beds in the eastern Adriatic Sea. Sci Mar 75:289-300

Christy FT (1973) Fisherman quotas: a tentative suggestion for domestic management. Law of the Sea Institute, University of Rhode Island. 19:7 pp

Clark JH, Kahn DM (2009) Amount and disposition of striped bass discarded in Delaware's spring striped bass gill-net fishery during 2002 and 2003: effects of regulations and fishing strategies. N Am J Fish Manag 29:576-585

Clark CW, Mangel M (2000) Dynamic state variable models in ecology: methods and applications. Oxford University Press, Oxford, p 304

Copes P (1986) A critical review of the individual quota as a device in fisheries management. Land Econ 62:278-291

Cullis-Suzuki S, McAllister M, Baker P, Carruthers T, Tate TJ (2012) Red snapper discards in the Gulf of Mexico: fishermen's perceptions following the implementation of individual fishing quotas. Mar Policy 36:583-591

Daan N (1997) TAC management in North Sea flatfish fisheries. J Sea Res 37:321-341

Davies NM (1992) Fisheries management-a New Zealand perspective. S Afr J Mar Sci 12:1069-1077

Depestele J, Vandemaele S, Vanhee W et al (2011) Quantifying causes of discard variability: an indispensable assistance to discard estimation and a paramount need for policy measures. ICES J Mar Sci 68:1719-1725

Dewees CM (1989) Assessment of the implementation of individual transferable quotas in New Zealand's inshore fishery. N Am J Fish Manag 9:131-139

Dewees CM (1998) Effects of individual quota systems on New Zealand and British Columbia fisheries. Ecol Appl 8:S133S138

Dickey-Collas M, Pastoors MA, van Keeken OA (2007) Precisely wrong or vaguely right: simulations of noisy discard data and trends in fishing effort being included in the stock assessment of North Sea plaice. ICES J Mar Sci 64:1641-1649

Dowling NA, Wilcox C, Mangel M, Pascoe S (2012) Assessing opportunity and relocation costs of marine protected areas using a behavioural model of longline fleet dynamics. Fish Fish 13:139-157

EFCA (2014) Webpage for the Joint Deployment Plan (JDP) of the European Fisheries Control Agency for North Sea and Western waters. http://efca.europa.eu/pages/home/jdp_ north.htm. Accessed 01-09-2014

Eliasen SQ, Papadopoulou K-N, Vassilopoulou V, Catchpole TL (2014) Socio-economic and institutional incentives influencing fishers' behaviour in relation to fishing practices and discard. ICES J Mar Sci 71:1298-1307

Feekings J, Bartolino V, Madsen N, Catchpole T (2012) Fishery discards: factors affecting their variability within a demersal trawl fishery. PLoS One 7:e36409

Feekings J, Lewy P, Madsen N (2013) The effect of regulation changes and influential factors on Atlantic cod discards in the Baltic Sea demersal trawl fishery. Can J Fish Aquat Sci 70:534-542

Fujita RM, Foran T, Zevos I (1998) Innovative approaches for fostering conservation in marine fisheries. Ecol Appl 8:S139-S150

Gillis DM (2003) Ideal free distributions in fleet dynamics: a behavioral perspective on vessel movement in fisheries analysis. Can J Zool 81:177-187

Gillis DM, Pikitch EK, Peterman RM (1995) Dynamic discarding decisions-foraging theory for high-grading in a trawl fishery. Behav Ecol 6:146-154

Gillis DM, Rijnsdorp AD, Poos JJ (2008) Behavioral inferences from the statistical distribution of commercial catch: patterns of targeting in the landings of the Dutch beam trawler fleet. Can J Fish Aquat Sci 65:27-37

Gray CA (2002) Management implications of discarding in an estuarine multi-species gill net fishery. Fish Res 56:177-192

Gray CA, Kennelly SJ (2003) Catch characteristics of the commercial beach-seine fisheries in two Australian barrier estuaries. Fish Res 63:405-422

Gray CA, Johnson DD, Broadhurst MK, Young DJ (2005) Seasonal, spatial and gear-related influences on relationships between retained and discarded catches in a multispecies gillnet fishery. Fish Res 75:56-72

Hamon KG, Thébaud O, Frusher S, Little LR (2009) A retrospective analysis of the effects of adopting individual transferable quotas in the Tasmanian red rock lobster, $\mathrm{Ja}$ sus edwardsii, fishery. Aquat Living Resour 22:549-558

Hannesson R (2013) Norway's experience with ITQs. Mar Policy 37:264-269 
Hara MM (2013) Efficacy of rights-based management of small pelagic fish within an ecosystems approach to fisheries in South Africa. Afr J Mar Sci 35:315-322

Harley SJ, Millar RB, McArdle BH (2000) Examining the effects of changes in the minimum legal sizes used in the Hauraki Gulf snapper (Pagrus auratus) fishery in New Zealand. Fish Res 45:179-187

Heery EC, Berkson J (2009) Systematic errors in length frequency data and their effect on age-structured stock assessment models and management. Trans Am Fish Soc 138:218-232

Holden MJT (1994) The common fisheries policy. Origin, evaluation and future, fishing. News Books, Oxford

Houston AI, McNamara JM (1999) Models of adaptive behaviour. Cambridge University Press, Cambridge

Kaplan IC, Holland DS, Fulton EA (2014) Finding the accelerator and brake in an individual quota fishery: linking ecology, economics, and fleet dynamics of US West Coast trawl fisheries. ICES J Mar Sci 71:308-319

Kelleher K (2005) Discards in the world's marine fisheries. An update. FAO Fisheries technical paper no. 470, Food and Agricultural Organization of the United Nations, Rome, Italy, $131 \mathrm{pp}$

Keskin Ç, Ordines F, Ates C, Moranta J, Massutí E (2014) Preliminary evaluation of landings and discards of the Turkish bottom trawl fishery in the northeastern Aegean Sea (eastern Mediterranean). Sci Mar 78:213-225

Kingsley M (2002) ITQs and the economics of high-grading. ICES J Mar Sci 59:649

Kraak SBM, Bailey N, Cardinale M, Darby C, De Oliveira JAA, Eero M, Graham N, Holmes S, Jakobsen T, Kempf A, Kirkegaard E, Powell J, Scott RD, Simmonds EJ, Ulrich C, Vanhee W, Vinther M (2013) Lessons for fisheries management from the EU cod recovery plan. Mar Policy 37:200-2013

Kristofersson D, Rickertsen K (2009) Highgrading in quotaregulated fisheries: evidence from the Icelandic cod fishery. Am J Agric Econ 91:335-346

Lehmann K, Degel H (1991) An estimate of shrimp discard from shrimp factory trawlers in Davis Strait and Denmark Strait. NAFO SCR Doc. 91/40. 11 pp

Liggins GW, Bradley MJ, Kennelly SJ (1997) Detection of bias in observer-based estimates of retained and discarded catches from a multi species trawl fishery. Fish Res 32:133-147

Macdonald P, Cleasby IR, Angus CH, Marshall CT (2014) The contribution of quota to the discards problem: a case study on the complexity of common megrim Lepidorhombus whiffiagonis discarding in the northern North Sea. ICES J Mar Sci 71:1256-1265

Mace PM, Sullivan KJ, Cryer M (2014) The evolution of New Zealand's fisheries science and management systems under ITQs. ICES J Mar Sci 71:204-215

Machias A, Maiorano P, Vassilopoulou V, Papaconstantinou C, Tursi A, Tsimenides N (2004) Sizes of discarded commercial species in the eastern-central Mediterranean Sea. Fish Res 66:213-222

Madsen N, Feekings J, Lewy P (2013) Discarding of plaice (Pleuronectes platessa) in the Danish North Sea trawl fishery. J Sea Res 75:129-134

Marçalo A, Araújo J, Pousão-Ferreira P, Pierce GJ, Stratoudakis Y, Erzini K (2013) Behavioural responses of sardines
Sardina pilchardus to simulated purse-seine capture and slipping. J Fish Biol 83:480-500

McCay BJ (1995) Social and ecological implications of ITQs: an overview. Ocean Coast Manag 28:3-22

Muse B, Schelle K (1989) Individual fisherman's quotas: a preliminary review of some recent programs. CFEC report 89-1

Neher PA (1994) Fishery management in Canda. In: Loayza EA (ed) Managing fishery resources: proceedings of a symposium co-sponsored by the World Bank and Peruvian Ministry of fisheries held in Lima, Peru, June 1992, pp 22-28. World Bank discussion papers 217

Olbers JM, Fennessy ST (2007) Retrospective assessment of the stock status of Otolithes ruber (Pisces: Sciaenidae) as bycatch on prawn trawlers from KwaZulu-Natal, South Africa. Afr J Mar Sci 29:247-252

Parslow J (2010) Individual transferable quotas and the "tragedy of the commons". Can J Fish Aquat Sci 67:1889-1896

Pascoe S (1997) Bycatch management and the economics of discarding. FAO Fisheries Technical paper 370, p 153

Pawlowski L, Lorance P (2009) Effect of discards on roundnose grenadier stock assessment in the Northeast Atlantic. Aquat Living Resour 22:573-582

Pikitch EK, Erickson DL, Wallace JR (1988) An evaluation of the effectiveness of trip limits as a management tool. NWAFC processed report 88-27. $37 \mathrm{pp}$

Poos JJ, Bogaards JA, Quirijns FJ, Gillis DM, Rijnsdorp AD (2010) Individual quotas, fishing effort allocation, and over-quota discarding in mixed fisheries. ICES J Mar Sci 67:323-333

Poos JJ, Turenhout MNJ, van Oostenbrugge HAE, Rijnsdorp AD (2013) Adaptive response of beam trawl fishers to rising fuel cost. ICES J Mar Sci 70:675-684

Press WH, Teukolsky AA, Vetterling WT, Flannery BP (2002) Numerical recipes in $\mathrm{C}++$. Cambridge University Press, Cambridge

Punt AE, Smith DC, Tuck GN, Methot RD (2006) Including discard data in fisheries stock assessments: two case studies from south-eastern Australia. Fish Res 79:239-250

Quirijns FJ, Poos JJ, Rijnsdorp AD (2008) Standardizing commercial CPUE data in monitoring stock dynamics: accounting for targeting behaviour in mixed fisheries. Fish Res 89:1-8

R Core Development Team (2013) R: A language and environment for statistical computing. R Foundation for Statistical Computing, Vienna, Austria. ISBN 3-900051-07-0. http://www.R-project.org/

Richards LJ (1994) Trip limits, catch, and effort in the British Columbia rockfish trawl fishery. N Am J Fish Manag 14:742-750

Rijnsdorp AD, Broekman PLV, Visser EG (2000) Competitive interactions among beam trawlers exploiting local patches of flatfish in the North Sea. ICES J Mar Sci 57:894-902

Rijnsdorp AD, Daan N, Dekker W, Poos JJ, Van Densen WLT (2007) Sustainable use of flatfish resources: addressing the credibility crisis in mixed fisheries management. J Sea Res 57:114-125

Rijnsdorp AD, Poos JJ, Quirijns FJ, Hille Ris Lambers R, De Wilde JW, Den Heijer WM (2008) The arms race between fishers. J Sea Res 60:126-138

Rijnsdorp AD, Poos JJ, Quirijns FJ (2011) Spatial dimension and exploitation dynamics of local fishing grounds by 
fishers targeting several flatfish species. Can J Fish Aquat Sci 68:1064-1076

Rijnsdorp AD, van Overzee HMJ, Poos J (2012) Ecological and economic trade-offs in the management of mixed fisheries: a case study of spawning closures in flatfish fisheries. Mar Ecol Prog Ser 447:179-194

Robinson C, Pascoe S (1998) Fisher behaviour: exploring the validity of the profit maximising assumption. In: Boude JP, Boncoeur J (eds) Proceedings of the Ninth Conference of the European Association of Fisheries Economists. Centre for the Economics and Management of Aquatic Resources (CEMARE), University of Portsmouth, UK, Discussion Paper 110, pp 167-183

Rochet M-J, Trenkel VM (2005) Factors for the variability of discards: assumptions and field evidence. Can J Fish Aquat Sci 62:224-235

Rochet MJ, Peronnet I, Trenkel VM (2002) An analysis of discards from the French trawler fleet in the Celtic Sea. ICES J Mar Sci 59:538-552

Salz P (1996) ITQs in the Netherlands: twenty years of experience. Document ICES CM 1996/P:18. 18 pp

Sanchirico JN, Holland D, Quigley K, Fina M (2006) Catchquota balancing in multispecies individual fishing quotas. Mar Policy 30:767-785

Santojanni A, Cingolani N, Arneri E, Kirkwood G, Belardinelli A, Giannetti G, Coleella S, Donato F, Barry C (2005) Stock assessment of sardine (Sardina pilchardus, Walb.) in the Adriatic Sea, with an estimate of discards. Sci Mar 69:603-617

Sauls B (2014) Relative survival of gags Mycteroperca microlepis released within a recreational hook-and-line fishery: application of the Cox Regression Model to control for heterogeneity in a large-scale mark-recapture study. Fish Res 150:18-27

Scott-Denton E, Cryer PF, Gocke JP, Harrelson MR, Kinsella DL, Pulver JR, Smith RC, Williams JA (2011) Descriptions of the US Gulf of Mexico reef fish bottom longline and vertical line fisheries based on observer data. Mar Fish Rev 73:1-26

Smith WE, Scharf FS (2011) Postrelease survival of sublegal southern flounder captured in a commercial gill-net fishery. N Am J Fish Manag 31:445-454

Soliman A (2014) Using individual transferable quotas (ITQs) to achieve social policy objectives: a proposed intervention. Mar Policy 45:76-81

Squires D, Kirkley J (1995) Resource rents from single and multispecies individual transferable quota programs. ICES J Mar Sci 52:153-164

Squires D, Campbell H, Cunningham S et al (1998) Individual transferable quotas in multispecies fisheries. Mar Policy 22:135-159

Stratoudakis Y, Fryer RJ, Cook RM (1998) Discarding practices for commercial gadoids in the North Sea. Can J Fish Aquat Sci 55:1632-1644

ter Hofstede R, Dickey-Collas M (2006) An investigation of seasonal and annual catches and discards of the Dutch pelagic freezer-trawlers in Mauritania, Northwest Africa. Fish Res 77:184-191

Tsagarakis K, Vassilopoulou V, Kallianiotis A, Machias A (2012) Discards of the purse seine fishery targeting small pelagic fish in the eastern Mediterranean Sea. Sci Mar 76:561-572

Turner MA (1997) Quota-induced discarding in heterogeneous fisheries. J Environ Econ Manag 33:186-195

Ulleweit J, Stransky C, Panten K (2010) Discards and discarding practices in German fisheries in the North Sea and Northeast Atlantic during 2002-2008. J Appl Ichthyol 26:54-66

Ulrich C, Reeves SA, Vermard Y, Holmes SJ, Vanhee W (2011) Reconciling single-species TACs in the North Sea demersal fisheries using the Fcube mixed-fisheries advice framework. ICES J Mar Sci 68:1535-1547

Van Beek FA, Rijnsdorp AD, Van Leeuwen PI (1983) Results of the mesh selection experiments on sole and plaice with commercial beam-trawl vessels in the North Sea in 1981. Document ICES CM 1983/B: 16. 24 pp

Van Beek FA, Van Leeuwen PI, Rijnsdorp AD (1990) On the survival of plaice and sole discards in the otter-trawl and beam-trawl fisheries in the North Sea. J Sea Res 26:151-160

van Marlen B, Wiegerinck JAM, van Os-Koomen E, van Barneveld E (2014) Catch comparison of flatfish pulse trawls and a tickler chain beam trawl. Fish Res 151:57-69

Van Overzee HMJ, Rijnsdorp AD (2015) Effects of fishing during the spawning period: implications for management. Rev Fish Biol Fish. doi:10.1007/s11160-014-9370-x

Van Putten IE, Kulmala S, Thébaud O, Dowling N, Hamon KG, Hutton T, Pascoe S (2012) Theories and behavioural drivers underlying fleet dynamics models. Fish Fish 13:216-235

Welch DJ, Mapstone BD, Begg GA (2008) Spatial and temporal variation and effects of changes in management in discard rates from the commercial reef line fishery of the Great Barrier Reef, Australia. Fish Res 90:247-260

Wood SN (2006) Generalized additive models: an introduction with R. Chapman and Hall/CRC Press, New York

Wood SN (2011) Fast stable restricted maximum likelihood and marginal likelihood estimation of semiparametric generalized linear models. J R Stat Soc B 73:3-36

Yergey ME, Grothues TM, Able KW, Crawford C, DeCristofer K (2012) Evaluating discard mortality of summer flounder (Paralichthys dentatus) in the commercial trawl fishery: developing acoustic telemetry techniques. Fish Res 115-116:72-81

Zimmermann F, Heino M (2013) Is size-dependent pricing prevalent in fisheries? The case of Norwegian demersal and pelagic fisheries. ICES J Mar Sci 70:1389-1395

Zuur AF, Ieno EN, Walker NJ, Saveliev AA, Smith GM (2009) Mixed effect models and extensions in ecology in R. Springer, New York 